\title{
EVALUATION THE PERFORMANCE OF CLAY BRICK WASTE IN THE REMOVAL OF BLUE DYES FROM POLLUTED WATER
}

${ }^{*}$ Shyama Talib Hussain ${ }^{1}$
Seroor Atalah Khaleefa $\mathrm{Ali}^{2}$

1) Graduate Student, Department of Environmental Engineering, College of Engineering, Mustansiriyah University, Baghdad, Iraq

2) Assistant Professor, Department of Environmental Engineering, College of Engineering, Mustansiriyah University, Baghdad, Iraq

\begin{abstract}
In this paper clay brick waste was applied as adsorbent material for Methylene blue dye removal from simulated wastewater. A series of tests were carried out at different conditions, such as solution $\mathrm{pH}$, initial concentration of Methylene blue dye, amount of adsorbent added and contact time. The best removal efficiency was obtained at $\mathrm{pH} 9$, adsorbent weight $2 \mathrm{~g}$, initial dye concentration $10 \mathrm{mg} / \mathrm{L}$ and contact time 30 minutes.

Results indicated that the clay brick waste are proper in removing dye from wastewater. The isotherm for the adsorption of dye on to the clay brick waste was tested by Freundlich and Langmuir isotherms and gave good results. FTIR images of Clay Brick Waste before and after adsorption were confirmed successfully the uptake of dye by brick waste.

Keywords: $C B W$, Methylene Blue Dye, Adsorption, Freundlich and Langmuir isotherms
\end{abstract}

\section{Introduction}

The recycling of waste water has become a global problem in worldwide to protect a sustainable future due to poor water sources which is considered a difficult problem at every place. Dye mainly released into waste waters by industries, dye manufacturing and textiles as well as other fabric finishing industries [1]. One of the major problems of waste waters should be treated the effluents of dyeing industry not only for their high chemical oxygen demand, but also for color, which is the first visual contaminant to the human. Improper disposal of these dye can lead to dangerous environmental problems due to their ecotoxicity [2,3], chemical composition and non-biodegradability nature, $[4,5]$. To develop cheaper and more effective technologies, there are many methods that have been studied in the last period. Among these methods, adsorption has received a great deal of attention because of its low cost, high efficiency, and easy operating conditions [6,7]. A large amount of clay brick waste (CBW) resulted from the demolition of old buildings due to the acceleration of construction and urban progress and its recycling process has played a significant role in our construction and environment [8]. $\mathrm{CBW}$ which is a silicate solid waste containing mainly $\mathrm{AI}_{2} \mathrm{O}_{3}$ and $\mathrm{SiO}_{2}$ these two amounts accounting $80 \%$ of the total other are $\mathrm{MgO}, \mathrm{CaO}$, $\mathrm{TiO}_{2}$ and $\mathrm{Fe}_{2} \mathrm{O}_{3}$ [9]. Since the CBW is mostly used, low cost, ecofriendly and available material, so it can be used as a good adsorbent [10]. 
Few studies have reported using CBW to remove dyes from polluted solution [9; 11; 12]. [9] Reported the remove of MBD from aqueous solutions using Brick Kiln Chamber Fly Ash (BKCFA) through batch mode studies. The maximum removal was attained at $\mathrm{pH} 11$. The optimum concentration for maximum removal of MBD by adsorption onto BKCFA were found to be $30 \mathrm{mg} / \mathrm{L}$. The optimum contact time for maximum percentage removal of MBD was found to be 30 minutes. The optimum dose rate for maximum percentage removal of MBD was found to be $1 \mathrm{~g} / \mathrm{L}$. The adsorption data were described well with Freundlich and Langmuir isotherms. They concluded the low-cost Brick Kiln Chamber Fly Ash is the best alternate for high cost commercial activated carbon for the removal of dye from textile effluents. [11] Studied on the batch adsorption of MBD, from aqueous solution ( $40 \mathrm{mg} / \mathrm{L}$ ) onto cedar sawdust and crushed brick in order to explore their potential use as low-cost adsorbents for wastewater dye removal. The results showed maximum adsorption capacities of 142.36 and $96.61 \mathrm{mg} / \mathrm{g}$ for cedar sawdust and crushed brick, respectively. The Influence of temperature and $\mathrm{pH}$ of the solution on adsorption process were also studied. The extent of the dye removal decreased with increasing the solution temperature and optimum $\mathrm{pH}$ value for dye adsorption was observed at $\mathrm{pH} 7$ for both adsorbents. The results indicate that cedar sawdust and crushed brick can be attractive options for dye removal from dilute industrial effluents. [12] Used the brick waste to remove basic blue 41 dye from an aqueous solution. The removal capacity increased with an increase in the initial concentration, temperature and the mass of brick waste used. The $\mathrm{pH}$ of the initial dye solution affected the removal capacity at values between 2 and 4 but remained unchanged at higher $\mathrm{pH}$ values above $\mathrm{pH}=10$.
The aims of this study were to use clay brick waste resulting from building demolition as an adsorbent material to remove methylene blue dye (MBD) from polluted water.

\section{Material and method}

\subsection{Basic methylene Blue}

The cationic dye was supplied from commercial market, at Baghdad city. Characteristics of the dye are shows in Table 1.

Table 1. Characteristic of the MB dye used in this study

\begin{tabular}{ll}
\hline Items & Methylene blue "MB" \\
Trade name & Methylene blue \\
Chemical formula & $\mathrm{C}_{16} \mathrm{H}_{18} \mathrm{CIN}_{3} \mathrm{~S}$ \\
Nature & Cationic \\
Phase & Solid/Powder \\
Wave length (nm) & 665 \\
Molecular weight g/mol & 319.85 \\
&
\end{tabular}

\subsection{Preparation of Clay Brick Waste (CBW)}

The CBW were collected from a construction site from the demolition of a building. The CBW was washed thoroughly many times with tab water then with distilled water and dried by air after that crashed into small pieces using a hammer and grounded into a powder form. The powdered $\mathrm{CBW}$ were stored in containers and screened through $(1.18 \mathrm{~mm})$ sized sieve. CBW was used in this study as shown in figure (1), its chemical properties are shown in Table 2. 


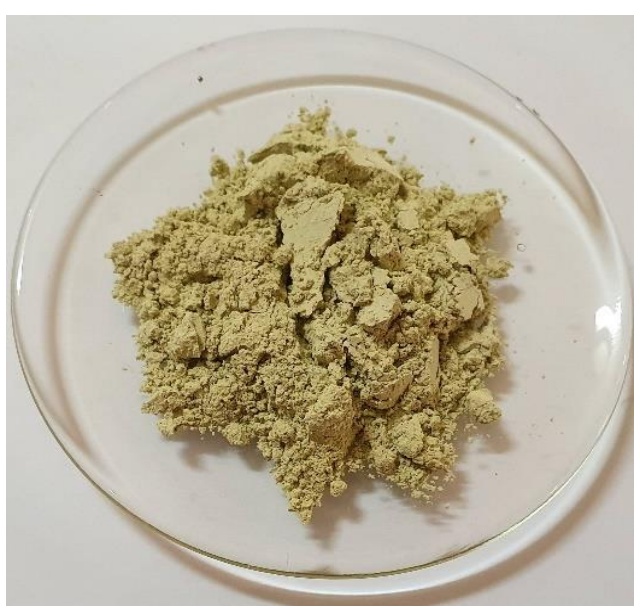

Figure 1. CBW

Table 2. Chemical analysis of CBW

\begin{tabular}{cc}
\hline Composition & Content (wt. \%) \\
$\mathrm{SiO}_{2}$ & 41.49 \\
$\mathrm{Al}_{2} \mathrm{O}_{3}$ & 9.36 \\
$\mathrm{CaO}$ & 28.82 \\
$\mathrm{Fe}_{2} \mathrm{O}_{3}$ & 5.602 \\
$\mathrm{~K}_{2} \mathrm{O}$ & 0.87 \\
$\mathrm{TiO}_{2}$ & 0.73 \\
$\mathrm{MgO}$ & 4.6 \\
\hline
\end{tabular}

\subsection{Batch Adsorption of dye}

Stock solutions of $1000 \mathrm{mg} / \mathrm{L}$ were prepared by adding one gram of MBD in $1000 \mathrm{~mL}$ of distilled water then diluted to the desired concentration. The adsorption experiments were carried out to evaluate the performance of $\mathrm{CBW}$ to remove MBD from polluted water as a function of $\mathrm{pH}$, adsorbent weight, adsorbate initial concentration and contact time on removal efficiency, all the experiments were done at room temperature $\left(25 \pm 5^{\circ} \mathrm{C}\right)$.

Prepared CBW a powder was used in different weights $(0.2,0.5,1,1.5,2,4,6$, and 8$)$ gm were added by500 mL conical flasks filled with 300
$\mathrm{mL}$ solution of $\mathrm{MB}$ with different initial concentrations $(10,20$ and30) $\mathrm{mg} / \mathrm{L}$. The mix was placed on a shaker-orbital with different mixing speeds 100, 200 and $300 \mathrm{rpm}$, while $\mathrm{pH}$ of the wastewater was varied from 5, 7 and 9 by adding $0.1 \mathrm{~N}$ HCL or $0.1 \mathrm{~N} \mathrm{NaOH}$ to get the desired $\mathrm{pH}$ checked by $\mathrm{pH}$-meter which is measure acidity or alkalinity in solution. The samples were collected every 30 minutes and filtered by using $(0.45 \mu \mathrm{m})$ filter paper diameter and dye concentration was measured by the spectrophotometer which used to find the absorbance after that the FTIR analysis was don for samples before and after adsorption to measure the functional group of the adsorbent material. The Final results of the removal efficiency were plotted as shown in the figures. Removal efficiency was calculated as follow [13].

$$
R(\%)=\frac{\left(C_{O}-C_{e}\right)}{C_{O}} * 100
$$

Where:

$\mathrm{R}(\%)=$ Removal efficiency

Then find Adsorption capacity (mg/g):

$$
q_{e}=\frac{V\left(C_{O}-C_{e}\right)}{M}
$$

Where:

M: adsorbent mass (g).

$\mathrm{V}$ : is solution volume $(\mathrm{L})$.

$\mathrm{q}_{\mathrm{e}}$ : is the adsorbed metal ions mass concentration, (mg/g).

$\mathrm{C}_{\mathrm{e}}$ and $\mathrm{C}_{\mathrm{o}}$ are equilibrium and initial concentrations $(\mathrm{mg} / \mathrm{g})$, respectively.

\section{Results and Discussions}

\subsection{Effect of $\mathbf{p H}$}

One of the most important factors in controlling the adsorption of dye is $\mathrm{pH}$, which was varied from 5, 7 and 9. The effect of $\mathrm{pH}$ on removal efficiency of MBD on the CBW at 60 min time. 
at $200 \mathrm{rpm}$ speed, $2 \mathrm{~g}$ and $10 \mathrm{mg} / \mathrm{L}$ of $300 \mathrm{ml}$ volume, temperature $\left(25 \pm 5^{\circ} \mathrm{C}\right)$ as shown in figure (2).

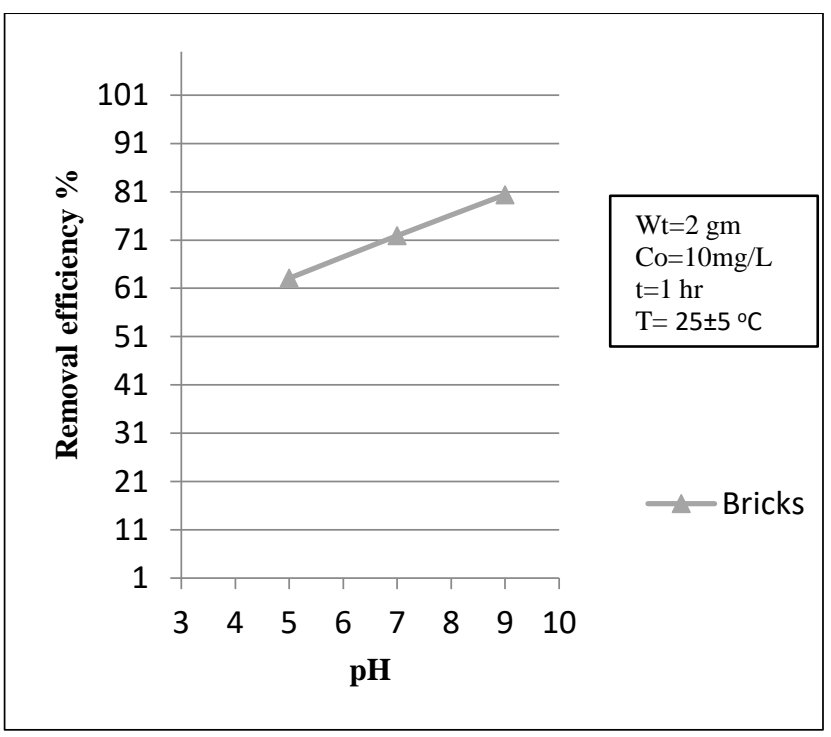

Figure 2. Effect of $\mathrm{pH}$ on removal efficiency of MBD using CBW.

Obviously from the figure, the removal efficiency of MBD increased with an increasing in $\mathrm{pH}$ value of solution and optimum removal efficiency $(80 \%)$ attained at $\mathrm{pH}=9$ which represented the best dye removal due to increased negative charge on the CBW surface, which leads to Electrostatic attraction with $\mathrm{MB}$ cationic dye. These results agree with the results of [9].

\subsection{Effect of Adsorbent weight}

To study the effect of CBW on MB adsorption many experiments were done by changing the adsorbent weight from $(0.2,0.5,1.5,1,2,4,6$, 8) $\mathrm{g}$ in a $10 \mathrm{mg} / \mathrm{L} \mathrm{MB}$ solution at room temperature with $\mathrm{pH} 9$, mixing time 60 minute and rotating speed was $200 \mathrm{rpm}$. All results are shown in figure (3).

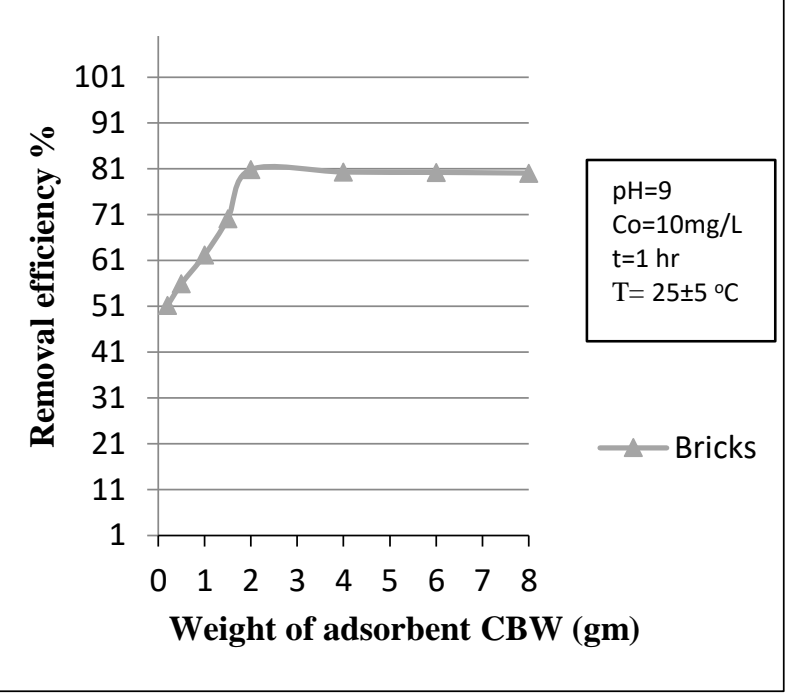

Figure 3. Effect of CBW weights on the removal efficiency of MBD.

An Increasing in the adsorbent weight until $2 \mathrm{gm}$ is thus seen to enhance increasing in the percentage removal of MBD until reaches equilibrium state, because of the availability of more adsorption sites and then occupied all active sites on the adsorbent surface thus leading to no significant increase in the dye removal efficiency. The optimal removal efficiency was found with an adsorbent dosage of $2 \mathrm{~g} / 300 \mathrm{~mL}$ to be ideal concentration for MBD removal. Which is in agreement with the findings of [9]

\subsection{Effect of initial dye Concentration}

The initial dye concentration has an important effect on the adsorption capacity by varying concentrations from $(10,20$ and $30 \mathrm{mg} / \mathrm{L})$ were selected by optimum conditions obtained from previous experiments $(\mathrm{pH} \mathrm{9,2} \mathrm{g})$ with contact time of 60 minute and rotating speed $200 \mathrm{rpm}$. Figure (4) shows results 


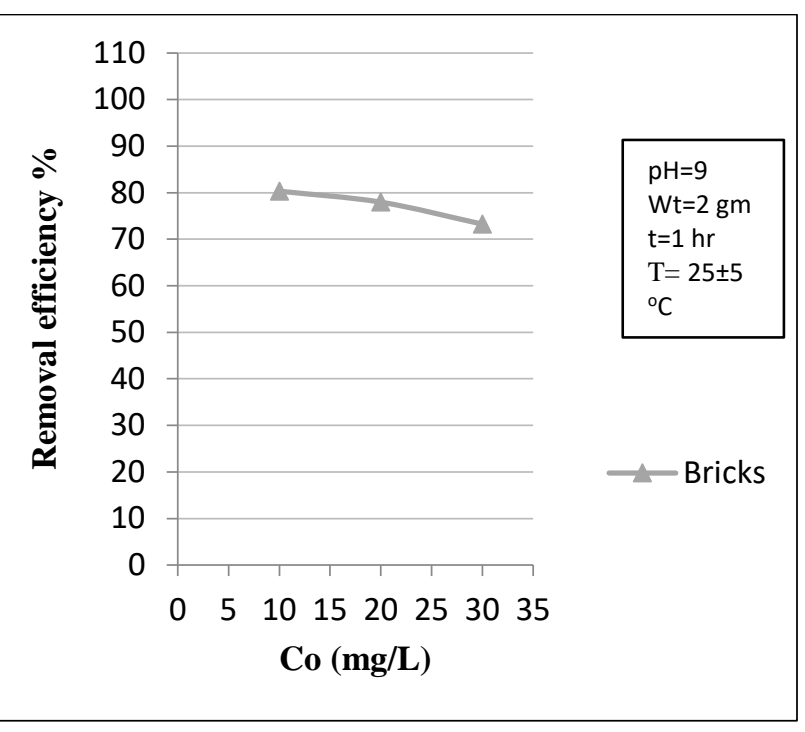

Figure 4. Influence of initial dye concentration on removal efficiency of $\mathrm{MBD}$

It was noticed that removal of MBD decreases with increasing concentration of dye where the highest percentage removal $(80 \%)$ was achieved within the $10 \mathrm{mg} / \mathrm{L}$ before the gradual decline due to absence of empty active sites required for adsorption of MB dye at high concentrations. Similar observation was reported by [9]

\subsection{Effect of contact time}

The percentage removal of MBD from solution was studied as shown in Figure (5), with $\mathrm{pH} 9$, mixing speed $200 \mathrm{rpm}$, adsorbent dosage $2 \mathrm{~g} / 300$ $\mathrm{mL}$ and $10 \mathrm{ppm}$ initial dye concentration.

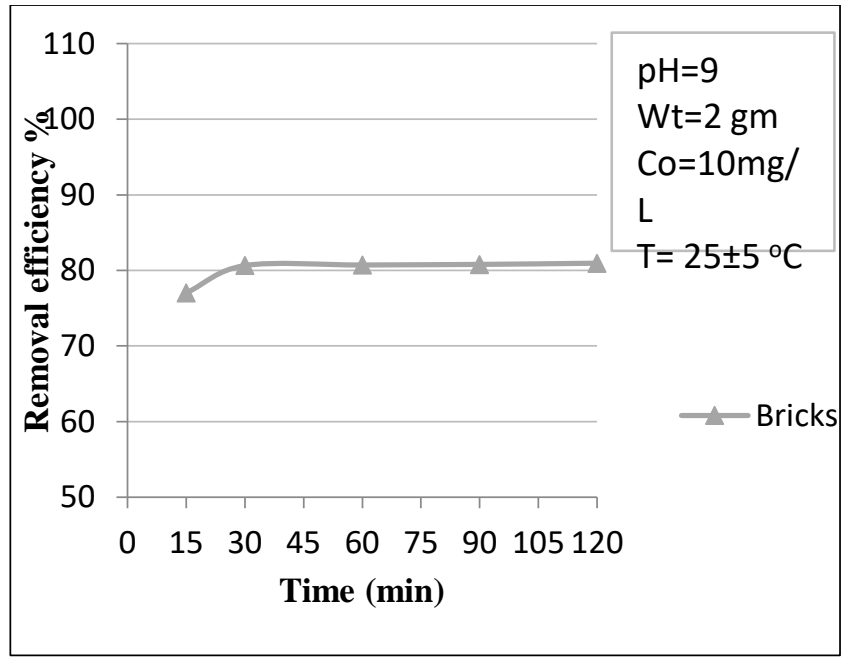

Figure 5. Impact of contact Time (min) on MBD removal
The removal efficiency increased with contact time until $30 \mathrm{~min}$ which was sufficient invariably to reach equilibrium. The adsorption rate was rapid in the beginning $(77 \%)$ at the time 15 minute which is attributed to an availability of more active sites on the bricks powder clay that are dominated by diffusion procedure of contaminated partials to surface of the adsorbent. At 30 minute the adsorption reached equilibrium due to the saturation of the active sites. Similar result was obtained by [9]

\subsection{Adsorption isotherms}

The adsorption isotherms were studied using Langmuir and Freundlich models. The Langmuir model is depended on the theoretical assumptions that existing adsorption positions are identical, energetically homogeneous and can only retain one molecule of the substance The Langmuir equation [14] is explained below:

$$
\frac{C_{e}}{q_{e}}=\frac{1}{\left(q_{m} * K_{L}\right)}+\frac{C_{e}}{q_{m}}
$$

Where:

$\mathrm{q}_{\mathrm{e}}=$ amount of adsorbate adsorbed at equilibrium $(\mathrm{mg} / \mathrm{g})$

$\mathrm{C}_{\mathrm{e}}=$ concentration of dye $(\mathrm{mg} / \mathrm{L})$ in the solution at equilibrium.

$\mathrm{q}_{\mathrm{m}}=$ monolayer adsorption capacity $(\mathrm{mg} / \mathrm{g})$

$\mathrm{K}_{\mathrm{L}}$ : is the Langmuir equilibrium constant $(\mathrm{L} / \mathrm{mg})$.

The Freundlich isotherm [15] describes heterogeneous surface adsorption, the formation of more than one layer is probable. The linear form of Freundlich equation is show as follow:

$$
\log q_{e}=\log K_{F}+\frac{1}{n \log C_{e}}
$$

Where:

$K_{F}=$ Freundlich adsorption isotherm constant, indicating the amount of adsorption $n=$ Freundlich constant related to adsorption intensity. 


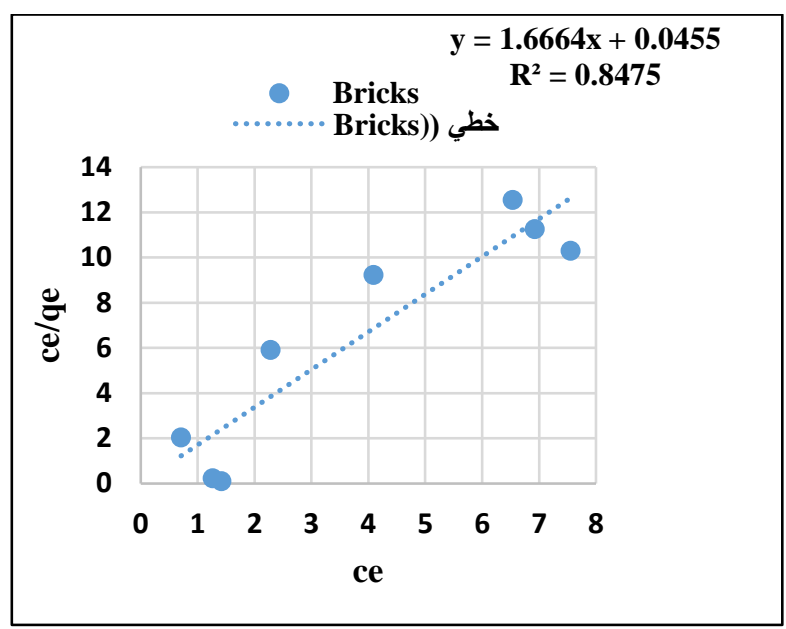

Figure 6. Langmuir adsorption isotherm for MBD (linear equation)

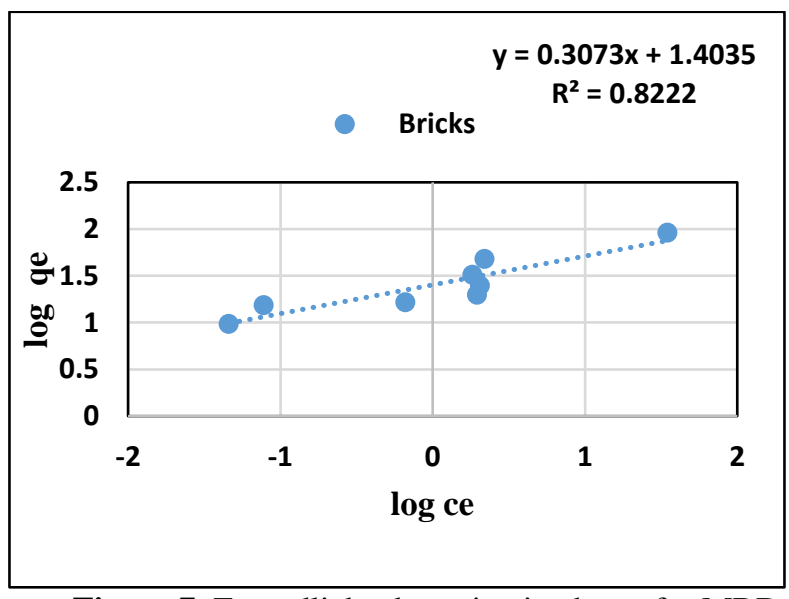

Figure 7. Freundlich adsorption isotherm for MBD (linear equation)

High adsorption capacity of CBW was examined at a room temperature, initial dye concentration of $10 \mathrm{ppm}, \mathrm{pH} 9$, with adsorbent dosage from $(0.2$ to $8 \mathrm{~g}$ ) in $300 \mathrm{ml}$ solutions and contact time 60 minute using the Langmuir and Freundlich equations. The correlation of equilibrium data $\left(\mathrm{R}^{2}\right)$ and the isotherm constants were presented in table 3 .
Table 3. Langmuir and Freundlich isotherm constants

\begin{tabular}{cccc}
\hline & Model & Parameters & Brick \\
& $\begin{array}{c}\text { Langmuir } \\
\text { Isotherm }\end{array}$ & $\mathrm{q}_{\mathrm{m}}(\mathrm{mg} / \mathrm{g})$ & 0.6 \\
& & $\mathrm{~K}_{\mathrm{L}}(\mathrm{L} / \mathrm{mg})$ & 36.63 \\
MBD & $\mathrm{R}^{2}$ & 0.8475 \\
& $\begin{array}{c}\text { Freundlich } \\
\text { Isotherm }\end{array}$ & $\begin{array}{c}\mathrm{KF}(\mathrm{mg} / \mathrm{g}) \\
(\mathrm{L} / \mathrm{mg})^{1 / \mathrm{n}}\end{array}$ & 25.322 \\
& & $\mathrm{~N}$ & 3.254 \\
& & $\mathrm{R}^{2}$ & 0.8222
\end{tabular}

The values of R2 for Langmuir and Freundlich models are 0.8475 and 0.822 respectively. Therefore, the Langmuir isotherm described the adsorption of $\mathrm{MB}$ on the $\mathrm{CBW}$ well and there is monolayer adsorption process occurs on the homogeneous distribution of active sites onto CBW surface.

\subsection{FTIR analysis of Clay Brick Waste (CBW)}

The FTIR Spectra of the (CBW), in the range of 400 - $4000 \mathrm{~cm}-1$ was taken to prove the existence of functional groups that might be responsible for the adsorption process before and after loaded of MBD as shown in Figure (8and9). It was noticed from table 4 the most functional group essential for MBD adsorption C-H 1,2,3 Trisubstituted, Alkene $\mathrm{C}=\mathrm{C}, \mathrm{C}-\mathrm{Br}$ halo compound. The alkane $\mathbf{C}-\mathbf{H}$ group may also be responsible for dye adsorption. Few groups such as O-H stretching, C-C Alkane, Fluoro compound $\mathrm{C}-\mathrm{F}$, Alkene $\mathrm{C}=\mathrm{C}$ are also responsible for pollutants adsorption on the surface of CBW. Total difference in the percentage of transmission (\%T) before and after adsorption is $99 \mathrm{~cm}^{-1}$ for MBD adsorption. 
Table 4. Functional group of CBW loaded by MBD

\begin{tabular}{|c|c|c|c|c|}
\hline $\begin{array}{l}\text { Waven } \\
\text { umber } \\
\mathrm{cm}^{-1}\end{array}$ & $\begin{array}{l}\text { Functional } \\
\text { group }\end{array}$ & $\begin{array}{c}\operatorname{Tr}(\%) \\
\text { before } \\
\text { adsorpt } \\
\text { ion }\end{array}$ & $\begin{array}{c}\operatorname{Tr}(\%) \\
\text { after } \\
\text { adsorpt } \\
\text { ion }\end{array}$ & $\Delta$ \\
\hline 3423 & $\begin{array}{c}\mathrm{O}-\mathrm{H} \\
\text { stretching }\end{array}$ & 78 & 70 & 8 \\
\hline 1732 & C-H Alkene & 79 & 76 & 3 \\
\hline 1622 & $\begin{array}{c}\text { C-C } \\
\text { Alkane }\end{array}$ & 77 & 68 & 9 \\
\hline 1935 & Alkane C-H & 65 & 55 & 10 \\
\hline 1059 & $\begin{array}{c}\text { Fluoro } \\
\text { compound } \\
\text { C-F }\end{array}$ & 9 & 2 & 7 \\
\hline 1036 & $\begin{array}{c}\text { Fluoro } \\
\text { compound } \\
\text { C-F }\end{array}$ & 11 & 3 & 8 \\
\hline 968 & $\begin{array}{c}\text { Alkene } \\
\mathrm{C}=\mathrm{C}\end{array}$ & 8 & 2 & 6 \\
\hline 723 & $\begin{array}{c}\text { C-H 1,2,3 } \\
\text { Trisubstitut } \\
\text { ed }\end{array}$ & 59 & 43 & 16 \\
\hline 679 & $\begin{array}{l}\text { Alkene } \\
\mathrm{C}=\mathrm{C}\end{array}$ & 49 & 33 & 16 \\
\hline 640 & $\begin{array}{l}\mathrm{C}-\mathrm{Br} \text { halo } \\
\text { compound }\end{array}$ & 47 & 31 & 16 \\
\hline & & & & 99 \\
\hline
\end{tabular}

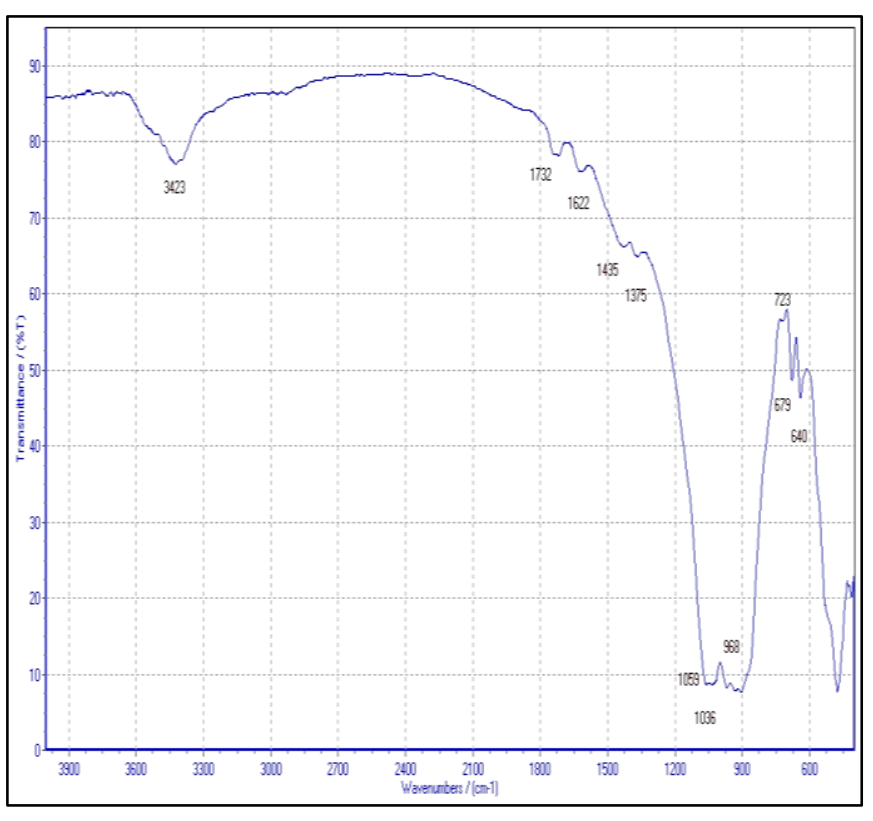

Figure 8. FTIR spectrum of CBW before adsorption

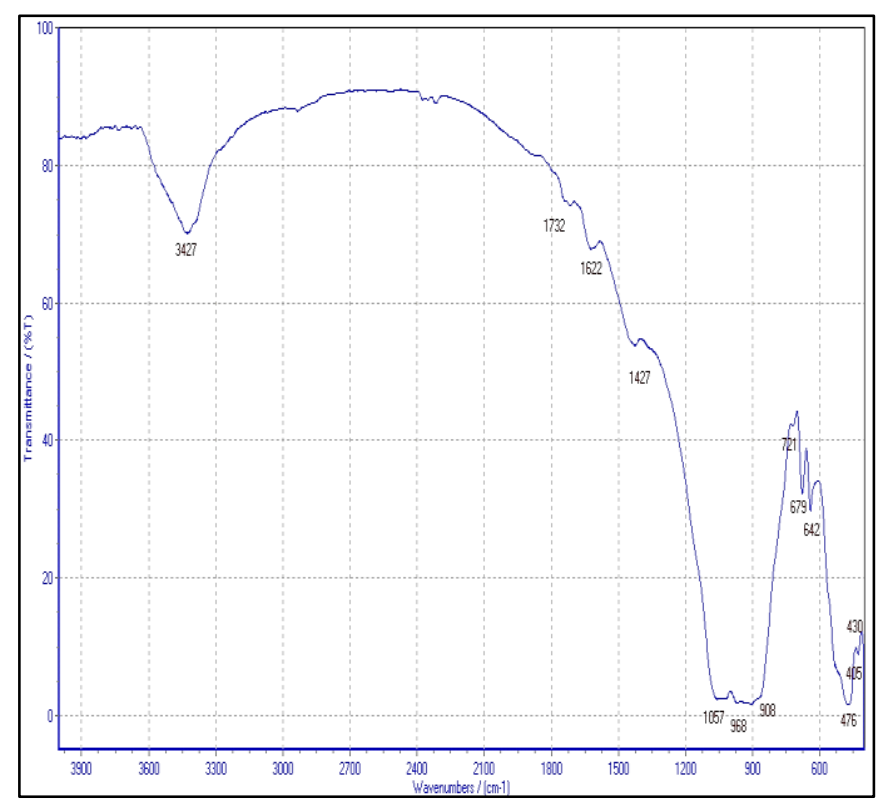

Figure 9. FTIR spectrum of CBW after adsorption.

\section{Conclusions}

The adsorption of MBD was strongly reliant on $\mathrm{pH}$ and best removal was achieved at $\mathrm{pH}$ 9. The optimum concentration for the maximum removal of MBD was found to be $10 \mathrm{ppm}$. The removal efficiency of MBD increased with the increase in the contact time and the suitable adsorption times are $60 \mathrm{~min}$. Adsorption data were described well with Freundlich and 
Langmuir isotherms. Langmuir model was fitted well for adsorption of methylene blue, and revealed that, dominant monolayer adsorption of MBD. The FTIR analysis observed that the C$\mathrm{H}$ 1, 2, 3 Trisubstituted was most functional group responsible for methylene blue adsorption. CBW as a good adsorbent material for remove MBD from aqueous solution and is economical adsorbent for the removal of MBD due to greater and easy abundance, ecofriendly and low cost.

\section{Acknowledgements}

The authors acknowledge the faculty and staff of the Sanitary Laboratory, Mustansiriyah University, for their valuable help in this research. The authors also acknowledge the Department of Environment and Water, Ministry of Science and Technology, for helping in testing that used in this research.

\section{Conflict of interest}

This research did not receive any specific grant from funding agencies in the public, commercial, or not for profit sectors. All equipment and materials used in this study were provided by Mustansiriyah University

\section{Abbreviations}

CBW clay brick waste

MBD methylene blue dye

\section{References}

1. Janos, P., Buchatora, H., and Ryznarova, M., (2003). "Sorption of Dye from Aqueous Solution on to Fly ash," Water Res.,37. https://doi.org/10.1016/j.watres.2003.08.01 $\underline{1 .}$

2. Vadivelan, V., Vasanth, K., (2005). "Equilibrium, kinetics, mechanism, and process design for the sorption of methylene blue onto rice husk". J. Colloid Interface Sci. 286. https://doi.org/10.1016/j.jcis.2005.01.07.
3. Gomez, V., Larrenchi, M.S., Callao, M.P., (2007). "Kinetic and adsorption study of acid dye removal using activated carbon". Chemosphere 69(7).

DOI: $\underline{10.1016 / j . c h e m o s p h e r e .2007 .03 .06}$

4. Metivier-Pigeon, H., Faur-Brasquet,C., and Cloirec, P L., (2003) "Adsorption of Dye on to Activated Carbon Cloths: Approach of Adsorption Mechanism and Coupling of ACC with Ultrafiltration to Treat Coloured Wastewaters". Separation and Purification Technology 31(1):3-11.

DOI: $\underline{10.1016 / \mathrm{S} 1383-5866(02) 00147-8}$

5. Waranusantigul, P., Pokethitiyook, P., Kruatrachue, M., and Upatham, E S., (2003) "Kinetics of basic dye (methylene blue) biosorption by giant duckweed (Spirodela polyrrhiza)". Environ. Pollution, 125. https://doi.org/10.1016/S02697491(03)0010 $\underline{7-6}$

6. Mondal M.K., (2009). "Removal of Pb (II) ions from aqueous solution using activated tea waste: adsorption on a fixed-bed column”. J. Environ. Manage. 90.

7. Aklil A., Mouflihb M., and Sebti S., (2004). "Removal of heavy metal ions from water by using calcined phosphate as a new adsorbent". J. Hazard. Mater. 112. DOI.org/10.1016/j.jhazmat.2004.05.018

8. Haili Cheng. (2016). "Reuse research progress on waste clay brick". Procedia Environmental Sciences 31. DOI: 10.1016/j.proenv.2016.02.029.

9. P. Govindaraj, N. Gnanavelraja, T. Subramanian and G. Bharath Balji. (2018). "Eco-Friendly Method to Detoxify Dye from Textile Effluent Using Bricks Kiln Chamber Fly Ash as Adsorbent". International 
Journal of Applied Engineering Research $0973456213,14$.

10. Sanjeet Kumar and Devesh Jaysawal. (2017). "A Study on Reuse of waste clay bricks". International Research Journal of Engineering and Technology (IRJET). 04: 11

11. Oualid Hamdaoui. (2006). "Batch study of liquid-phase adsorption of methylene blue using cedar sawdust and crushed brick". Journal of Hazardous Materials B135264273.

doi.org/10.1016/j.jhazmat.2005.11.062

12. Fethi Kooli, Liu Yan, Rawan Al-Faze, Awadh Al-Sehimi. (2015). "Removal enhancement of basic blue 41 by brick waste from an aqueous solution". Arabian Journal of Chemistry.

doi.org/10.1016/j.arabjc.2014.04.003

13. Seroor Atalah khaleefa Aki Khaleefa Ali, B.M. Fahad, H.T. Hamad. (2020). "Effect of ceramic waste as an adsorbent". OP Conference Series Materials Science and Engineering 737:012193.

DOI: $\underline{10.1088 / 1757-899 X / 737 / 1 / 012193}$

14. Juang, L. C., Wang, C C., Lee, C K., Hsu, T C., (2007). "Dye Adsorption onto Organoclay and MCM-41" J .Env. Eng. Manage, 17: 29-38.

15. Juang, L. C., Wang, C C., Lee, C K., (2006) "Adsorption of Basic Dye onto MCM-41" Chemosphere, 64 (11):1920-1928. DOI: 10.1016/j.chemosphere.2006.01.04 